\title{
CHARACTERISTICS OF POLISH UNIFLORAL HONEYS IV. HONEYDEW HONEY, MAINLY ABIES ALBA L.
}

\author{
Helena Rybak-Chmielewska*, Teresa Szczęsna, \\ Ewa Waś, Katarzyna Jaśkiewicz, Dariusz Teper
}

\author{
Research Institute of Horticulture, Apiculture Division, Department of Bee Products, \\ Kazimierska 2, 24-100 Puławy, Poland \\ *corresponding author: helena.chmielewska@man.pulawy.pl
}

Received 25 October 2012; accepted 17 May 2013

\section{$\mathrm{S} \mathrm{u} \mathrm{m} \mathrm{m} \mathrm{a} \mathrm{r} \mathrm{y}$}

Coniferous honeydew honey, mainly Abies alba was characterised. Samples chosen for the study had organoleptic traits characteristic for the variety: greenish, opalescence tone of brown colour, mild, sweet flavour with pleasant, slightly resinous aftertaste and aroma as well as electrical conductivity over $0.95 \mathrm{mS} / \mathrm{cm}$. To define composition and physicochemical parameters of the variety, contents of water and total sugars were determined. In addition various carbohydrates were identified and their contents were assessed as well. These were: fructose, glucose, sucrose, maltose, turanose, trehalose, isomaltose, malezitose. Other examined parameters related to honey quality were: free acidity, $\mathrm{pH}$, the content of 5-hydroxymetylofurfural (HMF), the main amino acid - proline, and the activity of $\alpha$-amylase enzyme (Diastase Number). The following properties were proven to be characteristic for this variety: high electrical conductivity with the average value of $1.14 \mathrm{mS} / \mathrm{cm}$, ranging from 0.96 to $1.32 \mathrm{mS} / \mathrm{cm}$; content of monosaccharides lower by few percent in relation to other honey varieties (from 58.2 to $67.4 \mathrm{~g} / 100 \mathrm{~g}$; on average $62.0 \mathrm{~g} / 100 \mathrm{~g}$ ) and a higher content of disaccharides and trisaccharide - melezitose. The presence of this sugar confirms that a considerable part of the honey was produced from honeydew. The average value of melezitose was $3.2 \mathrm{~g} / 100 \mathrm{~g}$, ranging from 0.9 to $5.9 \mathrm{~g} / 100 \mathrm{~g}$. Also, the results of the $\mathrm{pH}$ measurements were slightly higher than in other honey varieties (from 4.23 to 4.99; on average 4.63). The colour value in mm Pfund ranged from 74 to 105 , with the average of 93 .

Keywords: Abies alba, coniferous honeydew honey, characteristics, organoleptic traits, physicochemical parameters, melezitose, Poland.

\section{INTRODUCTION}

This work is a continuation of the research on the characteristics of Polish honey varieties. Previous parts of these results were presented by Szczęsna et. al. (2011) and Waś et. al. (2011a; 2011b).

According to the Polish Standard (PN88/A-77626, 1998), two varieties of honeydew honey are distinguished: deciduous honeydew honey and coniferous honeydew honey. Polish coniferous honeydew honey is mainly produced from Abies alba. Abies alba occurs mainly in southern and south-eastern Poland. The Podkarpacie Region and Świętokrzyskie Mountains are the largest habitats of oldgrowth fir trees. They are one-of-a-kind areas, overgrown with fir tree forests (Demianowicz, 1953; Haragsim, 1970; Crane and Walker, 1985; Gałuszka and Tworek, 1993; Tworek, 1998; Witkowska-Żuk, 2008).

Once every couple of years, when the weather conditions are favourable for aphids, the Abies alba becomes a rich source of honeydew honey. Last time it was harvested in 2006 and 2007. Coniferous honeydew honey is the most expensive variety (besides heather honey) available on the domestic market.

Aphids foraging on Abies alba produce honeydew. The most significant aphid species is Cinara pectinatae (Nördl.) from the Lachnidae family. Cinara pectinatae is 
the main producer of honeydew in Poland. Under favourable weather conditions, in July and August, frequently also in September, Cinara pectinatae occurs in vast numbers. Bees start to collect honeydew when it is available in an apiary's vicinity in high quantities. Temperature has the highest influence on aphid development and growth, and this way on honeydew occurrence. The aphid population peak occurs in temperatures from $25^{\circ} \mathrm{C}$ to $30^{\circ} \mathrm{C}$. On the other hand, heavy rains and sudden temperature drops significantly decrease aphid population numbers, this way minimizing the possibility of honeydew occurrence in quantities significant for beekeepers (Gałuszka et al., 1987).

The results of composition, characteristics, and quality parameters of the honeydew honey were presented first and foremost in two extensive research works (Haragsim, 1970; Liebig, 1979), and in papers concerning the comparison of the results of physicochemical analyses for different honey varieties, honeydew honey among others: Imdorf et al. (1985a), Imdorf et al. (1985b), Rybak (1986), von der Ohe W. and von der Ohe K. (1996), Szczęsna et al. (2003), Persano Oddo and Piro (2004), RybakChmielewska (2007), Bertoncelj et al. (2011), and Manzanares et al. (2011). Persano Oddo and Piro (2004) introduced the results of their analysis of 6719 samples of 15 gathered varieties, including honeydew honey, mainly from Abies alba and Picea excelsa. These researches were conducted by the IHC (International Honey Commission).

Detailed guidelines referring to the physicochemical properties of honey are contained in the Regulation of the Ministry of Agriculture and Rural Development of Oct. 3, 2003 (Rozporządzenie Ministra Rolnictwa i Rozwoju Wsi $z$ dnia 3 października 2003), which is in agreement with the EU Directive (Council Directive, 2002).

The aim of the study was to characterize coniferous, mainly Abies alba, honeydew honey harvested in south-eastern Poland.

\section{MATERIAL AND METHODS}

The study was conducted in the accredited Bee Products Quality Testing Laboratory of the Research Institute of Horticulture, Apiculture Division in Pulawy, Poland. The material for the research - coniferous honeydew honey samples collected in 2006 and 2007 - came from the beekeepers of the Podkarpacie Region. 27 samples of honeydew honey, mainly Abies alba were analysed after confirmation of the honey variety on the basis of organoleptic traits, values of electrical conductivity, and occurrence of elements typical for coniferous honeydew honey in the sediment. Samples were stored at room temperature and physicochemical analyses were done within a month from the collection of honey.

Microscopic slides, to verify the presence of honeydew elements in honeys, were prepared according to the pollen analysis methods recommended by the International Commission of Bee Botany and International Honey Commission (Louveaux et al., 1978).

Organoleptic traits - colour (liquid and after crystallization), aroma, flavour, and consistency and crystallisation pattern were assessed using the organoleptic features requirements detailed in the Polish Standard (PN-88/A-77626, 1998). In addition, the colour of liquid honey was defined in the mm Pfund scale by the colorimetric method and using the Lovibond PFX 195 colorimeter (Fell, 1978; Bogdanov et. al., 2004).

The following physicochemical parameters were defined: water content, free acids and $\mathrm{pH}$, electrical conductivity, diastase number (DN), quantity and quality analyses of sugars, 5-hydroxymethylfurfural (HMF), and proline content. These parameters were assayed according to the methods elaborated by the International Honey Commission (Bogdanov et. al., 1997; Bogdanov et. al, 2004). The methods are detailed and applied to obligatory usage in Poland for honey quality assessment by the Regulation of the Ministry of Agriculture 
and Rural Development of Jan. 14, 2009 (Rozporządzenie Ministra Rolnictwa i Rozwoju Wsi z dnia 14 stycznia 2009).

The results were processed statistically. Means, standard deviations, and coefficients of variation for individual features characterising the variety were calculated.

\section{RESULTS}

Elements typical for coniferous honeydew were observed under microscope. In samples of the honey sediment, there were different kinds of honeydew elements. Microalgae - usually species of green algae (Chlorophyceae) (Fig. 1a), and fungi spores (Fig. 1b) were found. Sooty moulds (Fungi imperfecti), sometimes visible as dark brown or black coats on leafs, needles, and bark are typical for honeydew honeys.

Organoleptic traits characteristic for coniferous honeydew honey, mainly Abies alba is first of all colour. Liquid honey was brown to almost black with a greenish, slightly opalescent tone. After crystallization the colour became lighter, usually with a clear grey-greenish or brown-greenish tone. The greenish tone of brown or grey-brown colour is a feature characteristic for this variety of honeydew honey. In the mm Pfund scale, the colour of the studied samples was from 74 to 104 , on the average of 93 (Tab. 1). Fresh samples of this honey variety had quite strong, characteristic aroma, slightly resembling the aroma of fir needles and resin. The honey had a mild, sweet flavour with a bit of resinous aftertaste.

Results for physicochemical parameters of honeydew, mainly Abies alba honey samples are presented in Table 1. In the examined samples, the content of water varied from 15.3 to $18.1 \%$, with the average of $16.8 \%$.

The content of monosaccharides (a sum of fructose and glucose) ranged from 58.2 to $67.4 \mathrm{~g} / 100 \mathrm{~g}$, and the average was $62.0 \mathrm{~g} / 100 \mathrm{~g}$. Fructose content was between 31.5 and $38.2 \mathrm{~g} / 100 \mathrm{~g}$, with the average of $34.2 \mathrm{~g} / 100 \mathrm{~g}$. The glucose content ranged from 24.3 to $30.0 \mathrm{~g} / 100 \mathrm{~g}$, with the average being $27.8 \mathrm{~g} / 100 \mathrm{~g}$, and was about $6-7 \mathrm{~g} / 100 \mathrm{~g}$ lower than the content of fructose. Sucrose content varied from $<0.5$ to $2.3 \mathrm{~g} / 100 \mathrm{~g}$. Other disaccharides that were determined are: turanose, maltose, trehalose, and isomaltose. The average value of the total content of disaccharides was $8.9 \mathrm{~g} / 100 \mathrm{~g}$, and varied from 4.1 to $15.5 \mathrm{~g} / 100 \mathrm{~g}$. The biggest part of this amount was maltose - the average $3.2 \mathrm{~g} / 100 \mathrm{~g}$, from 1.9 to $4.4 \mathrm{~g} / 100 \mathrm{~g}$. The trehalose content was from 0.6 to 4.9 , and on the average of $2.7 \mathrm{~g} / 100 \mathrm{~g}$. The mean content of two remaining sugars was even lower: turanose - 1.8 and isomaltose - $1.2 \mathrm{~g} / 100 \mathrm{~g}$, on average. In the studied samples the average content of melezitose was $3.2 \mathrm{~g} / 100 \mathrm{~g}$, with the lowest value of 0.9 and the highest of $5.9 \mathrm{~g} / 100 \mathrm{~g}$.

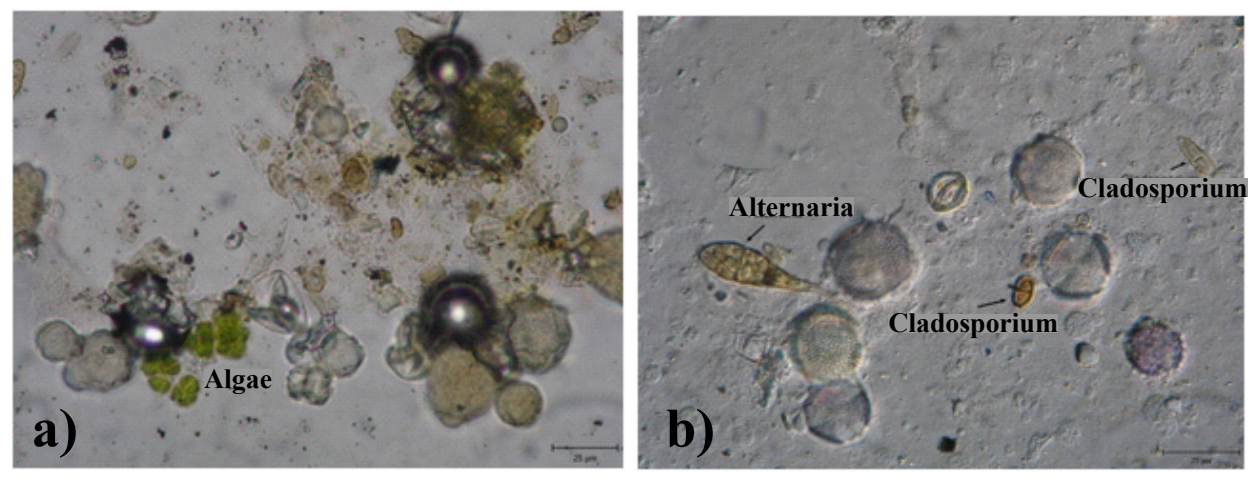

Fig. 1. Microscopic view of honeydew elements in honeydew honey

a) green algae - characteristic for coniferous honeydew honeys;

b) fungi spores - honeydew elements that occur in coniferous and deciduous honeydew honeys. 
Physicochemical properties of honeydew honey, mainly Abies alba

\begin{tabular}{|c|c|c|c|c|}
\hline Parameter & Unit & Min - Max & Mean \pm SD & CV (\%) \\
\hline Colour & $\mathrm{mm}$ Pfund & $74-104$ & $93 \pm 8.3$ & 8.9 \\
\hline Water & $\%$ & $15.3-18.1$ & $16.8 \pm 0.8$ & 4.8 \\
\hline Fructose $(\mathrm{F})$ & $g / 100 \mathrm{~g}$ & $31.5-38.2$ & $34.2 \pm 1.3$ & 3.9 \\
\hline Glucose (G) & $g / 100 \mathrm{~g}$ & $24.3-30.0$ & $27.8 \pm 1.3$ & 4.5 \\
\hline$F+G^{*}$ & $\mathrm{~g} / 100 \mathrm{~g}$ & $58.2-67.4$ & $62.0 \pm 1.9$ & 3.1 \\
\hline $\mathrm{F} / \mathrm{G}^{* *}$ & - & $1.1-1.5$ & $1.2 \pm 0.1$ & 5.9 \\
\hline Saccharose & $g / 100 \mathrm{~g}$ & $<0.5^{* * *}-2.3$ & - & - \\
\hline Turanose & $\mathrm{g} / 100 \mathrm{~g}$ & $1.2-3.7$ & $1.8 \pm 0.5$ & 27.1 \\
\hline Maltose & $g / 100 \mathrm{~g}$ & $1.9-4.4$ & $3.2 \pm 0.6$ & 17.4 \\
\hline Trehalose & $g / 100 \mathrm{~g}$ & $0.6-4.9$ & $2.7 \pm 1.1$ & 39.9 \\
\hline Izomaltose & $g / 100 \mathrm{~g}$ & $<0.5^{*+*}-5.5$ & - & - \\
\hline Melezitose & $g / 100 \mathrm{~g}$ & $0.9-5.9$ & $3.2 \pm 1.3$ & 40.8 \\
\hline Sugars in total & $g / 100 \mathrm{~g}$ & $71.6-77.9$ & $75.3 \pm 1.7$ & 2.2 \\
\hline Diastase number (DN) & Schade & $20.2-56.6$ & $28.4 \pm 9.4$ & 33.2 \\
\hline HMF & $\mathrm{mg} / \mathrm{kg}$ & $<0.5^{*+*}-4.8$ & - & - \\
\hline Free acidity & $\mathrm{mval} / \mathrm{kg}$ & $20.1-34,2$ & $27.6 \pm 4.1$ & 14.7 \\
\hline $\mathrm{pH}$ & & $4.23-4.99$ & $4.63 \pm 0.18$ & 4.0 \\
\hline Electrical conductivity & $\mathrm{mS} / \mathrm{cm}$ & $0.96-1.32$ & $1.14 \pm 0.1$ & 8.9 \\
\hline Proline & $\mathrm{mg} / 100 \mathrm{~g}$ & $37.7-99.0$ & $64.9 \pm 22.1$ & 34.1 \\
\hline
\end{tabular}

* sum of monosaccharides (fructose and glucose)

** fructose to glucose ratio

$* * *$ limit of determination

Activity of $\alpha$-amylase determined by the diastase number (DN) was relatively high with the average value of 28.4 in Schade units, from 20.2 to 56.6. In the majority of the tested samples very low content of HMF was found; at the level below limit of determination $(0.5 \mathrm{mg} / \mathrm{kg})$ to $4.8 \mathrm{mg} / \mathrm{kg}$. The $\mathrm{pH}$ fluctuated from 4.23 to 4.99 , with the average of 4.63 . The values of free acidity varied from 20.1 to 34.2 $\mathrm{mval} / \mathrm{kg}$, with the average of $27.6 \mathrm{mval} / \mathrm{kg}$. Electrical conductivity had an average value of $1.14 \mathrm{mS} / \mathrm{cm}$, from 0.96 to 1.32 $\mathrm{mS} / \mathrm{cm}$. The range for proline content was from 37.7 to $99.0 \mathrm{mg} / 100 \mathrm{~g}$, on average $64.9 \mathrm{mg} / 100 \mathrm{~g}$.

Colour, water, fructose and glucose content, $\mathrm{pH}$ and electrical activity presented low variability within this honey variety. Coefficient of variation was less than $10 \%$ for all of these parameters. The samples were characterized by high variability the contents of: melezitose $(\mathrm{CV}=40.8 \%)$, trehalose $(\mathrm{CV}=39.9 \%)$, turanose $(\mathrm{CV}=27.1 \%)$, and proline $(\mathrm{CV}=34.1 \%)$; as well as diastase number $(\mathrm{CV}=33.2 \%)$.

\section{DISCUSSION}

To compare the coniferous honeydew honey with other varieties the following parameters can be used: amount of sugars (especially fructose, glucose, melezitose), electrical conductivity, $\mathrm{pH}$, colour and proline. Some physicochemical parameters of unifloral honeys undergo changes e.g. during storage or heating (HMF, diastase activity). Examined samples were analyzed after short storage time (within a month from the collection of honey) and all tested parameters complied requirements of different standards (PN-88/A-77626, 1998; Rozporządzenie Ministra Rolnictwa i Rozwoju Wsi z dnia 3 października 2003; EU Directive, 2002).

According to the results presented in this paper honeydew honey has a relatively low water content. Similar low levels of water content in Polish honeydew honeys were found by Rybak (1986) and Szczęsna et al. (2003). Also in European honeydew honeys, Persano Oddo and Piro (2004) determined the average water content 
at $16.1 \%$. In the bibliographical review concerning unifloral honey characteristics, Piazza and Persano Oddo (2004) compared different features including water content in unifloral honeys (12 papers from different countries) and except for two honeys, the average values were below $18.0 \%$.

Total content of monosaccharides was lower by few percent in relation to other honey varieties. In honeydew honeys from different European countries (Persano Oddo and Piro, 2004), the average content of monosaccharides was $58.7 \mathrm{~g} / 100 \mathrm{~g}$, from 51.2 to $66.2 \mathrm{~g} / 100 \mathrm{~g}$. These results confirmed our previous reports (Rybak-Chmielewska, 2007) that coniferous honeydew honey contains $6.0 \%-10.0 \%$ less monosaccharides than floral honey.

Results similar to ours considering the fructose content in Polish honeydew honeys where obtained earlier by Krauze and Zalewski (1991) - the average of $34.0 \mathrm{~g} / 100 \mathrm{~g}$, from 29.9 to $35.9 \mathrm{~g} / 100 \mathrm{~g}$. Honeydew honey from Slovenia had similar values of fructose content (Golob and Plestenjak, 1999); the average of $34.2 \mathrm{~g} / 100 \mathrm{~g}$, ranging from 30.8 to $37.6 \mathrm{~g} / 100 \mathrm{~g}$. Also, ours results did not differ much from the average and extreme values for 362 samples of honeydew honeys from different European countries (Persano Oddo and Piro, 2004) the average $32.5 \mathrm{~g} / 100 \mathrm{~g}$, from 28.7 to $36.2 \mathrm{~g} / 100 \mathrm{~g}$.

Values of glucose content in honeydew honeys from Poland determined by Krauze and Zalewski (1991) were a little higher. The average sugar content was $30.9 \mathrm{~g} / 100 \mathrm{~g}$, and the range was from 27.9 to $33.2 \mathrm{~g} / 100 \mathrm{~g}$. Whereas the results of glucose content compiled by Persano Oddo and Piro (2004) on the basis of studies from different countries of Europe in 362 samples of honeydew honeys turned out to be slightly lower. The average content of glucose was $26.2 \mathrm{~g} / 100 \mathrm{~g}$, ranging from 21.3 to $31.1 \mathrm{~g} / 100 \mathrm{~g}$.

In general, it was noticeable that the total content of disaccharides was about twice higher than in floral honeys. Sucrose content turned out to be at least two times lower than the requirements for this variety of honey - not more than 5\% (Rozporządzenie Ministra Rolnictwa i Rozwoju Wsi z dnia 3 października 2003). Other authors also reported low sucrose content: Krauze and Zalewski (1991), Szczęsna et al. (2003), and Persano Oddo and Piro (2004). The average value in their studies was $0.98,0.2$ and $0.8 \mathrm{~g} / 100 \mathrm{~g}$, respectively. The results obtained in the above-mentioned papers were similar to ours.

The content of melezitose (trisaccharide also known as larch sugar) is characteristic for honeydew honeys. It is present in honeys made from both deciduous and coniferous honeydew. Similar contents of this sugar were determined in honey samples obtained from beekeepers from southern Poland in 2003 (Szczęsna et al., 2003). In nectar honey characterized by Szczęsna et. al. (2011) and Waś et. al. (2011a; 2011b) melezitose was not present. In general, the presence of melezitose confirms that a substantial part of honey was made from honeydew.

Our results for diastase activity of coniferous honeydew honey was very high. A high value of this parameter was also determined in the studied coniferous honeydew honeys from Poland (Szczęsna et al., 2003) with the average value of 24.7, from 16.7 to 38.3 .

Results of $\mathrm{pH}$ were slightly higher than in other honey varieties. Other authors had determined similar values of acidity for this honey variety (Szczęsna et al., 2003; Persano Oddo and Piro, 2004). The values of acidity in their studies were: $27.0 \mathrm{mval} / \mathrm{kg}$ (the average value), from 15.0 to 41.0 and 26.0 , from 16.8 to $37.1 \mathrm{mval} / \mathrm{kg}$, respectively. This indicates that some acids are present in honey. The higher the acids content the more spiciness we can taste in the honey sweet flavour. Moderate acidity deepens the flavour bouquet but does not give the impression of spiciness. Coniferous honeydew honey is being described as sweet and mild. 
The value of electrical conductivity can be helpful in determining honeydew honeys as it is an obligatory requirement ambiguously distinguishing the honeydew honey types (Rozporządzenie Ministra Rolnictwa i Rozwoju Wsi z dnia 3 października 2003). The Polish Standard (PN-88/A-77626, 1998) describes them more precisely. According to that document the value of conductivity for deciduous honeydew honey ranges from 0.80 to 0.95 . The highest values, over 0.95 , are ascribed to coniferous honeydew honeys. Deciduous honeydew honeys can sometimes have also higher value of this parameter (above $0.95 \mathrm{mS} / \mathrm{cm}$ ). For honeydew honey classification, apart from electrical conductivity, organoleptic traits should be taken into account. More significant differences in the electrical conductivity were noticed between coniferous honeydew honey results presented in this paper in comparison to values obtained for domestic nectar honeys by Szczęsna et. al. (2011) and Waś et. al. (2011a; 2011b).

The proline value for coniferous honeydew honey presented in this paper was decisively high in comparison to nectar honey. The requirement concerning minimum of proline content $(25 \mathrm{mg} / 100 \mathrm{~g})$ is described in the Polish Standard (PN88/A-77626, 1998). Proline content in the tested samples was much higher than the minimum required and also higher than the content presented in the results obtained by Persano Oddo and Piro (2004). Proline values received for honeydew honey in our studies were also higher than values received by $\mathrm{W}$ aś et. al. (2011b) for heather honey so far considered a honey with the highest proline content.

Unique organoleptic properties and some of physicochemical parameters characteristic for honeydew honey samples collected by beekeepers from the Podkarpacie Region presented in this paper were the basis for registration in the European Union of "Podkarpacki Miód Spadziowy" as a product with protected designation of origin (Rozporządzenie Komisji (UE) $\mathrm{Nr} 710 / 2010$ z dnia 6 sierpnia 2010 r.).

\section{CONCLUSIONS}

1. The following features turned out to be characteristic for honeydew honey, mainly Abies alba: high electrical conductivity (above $0.95 \mathrm{mS} / \mathrm{cm}$ ), total content of monosaccharides lower by few percent in relation to other honey varieties, and a higher content of disaccharides.

2 . The presence of melezitose in honey confirms that a considerable part of this honey was made from honeydew.

3. Abies alba honeydew honey was also characterised by higher $\mathrm{pH}$ values and proline content in relation to other honey varieties.

4. The greenish tone of brown colour in liquid honey and of grey-greenish or brown-greenish colour in crystallised honey is characteristic for coniferous honeydew honey. The mild, sweet flavour of this variety has a hint of a resinous aftertaste and aroma.

\section{REFERENCES}

Bogdanov S., Martin P., Lüllmann C. (1997) - Harmonised methods of the European Honey Commission. Apidologie, extra issue: 1-59.

Bogdanov S., Ruoff K., Persano Odo L. (2004) - Physico-chemical methods for the characterization of unifloral honeys: a review. Apidologie, 35: 4-17.

Bertoncelj J., Golob T., Kropf U., Korośec M. (2011) - Characterisation of Slovenian honeys on the basis of sensory and physicochemical analysis with a chemometric approach. Int. J. Food Sci. Tech., 46: 16611671.

Crane E., Walker P. (1985) - Important honeydew sources and their honeys. Bee World, 66: 105-112.

Council Directive 2001/110 EC of 20 December 2001 relating to honey (2002). Off. J. Eur. Commun. L, 10: 47-52.

Demianowicz Z. (1953) - Rośliny miododajne. [Melliferous plants], PWRiL, Warszawa, $161 \mathrm{pp}$. 
Fell R. D. (1978) - The color grading of honey. Am. Bee J., 18: 782-789.

Gałuszka H., Tworek K. (1993) - Die Haufigkeit der Honigtauausscheidung von die populationsdichte von Cinara pectinatea (Nordl). Pszczeln. Zesz. Nauk., 37: 113-121.

Gałuszka H., Ostrowska W., Kędracki T. (1987) - Gospodarka pasieczna w terenach spadziowych. [Beekeeping technology in the areas of honeydew], PWRiL, Poznań, 116 pp.

Golob T., Plestenjak A. (1999) - Quality of Slovene honey, Food Technol. Biotechnol., 37: 195-201.

Haragsim O. (1970) - Spadź i pszczoły. [Honeydew and bees]. PWR i L, Warszawa, $250 \mathrm{pp}$.

Imdorf A., Bogdanov S., Kilchenmann V. (1985a) - Zementhonig im Honig und Brutraum - was dann? I. Teil: Wie überwinter Binenvölkerauf Zementhonig. Schweiz. Binenztg., 108(10): 534-544.

Imdorf A., Bogdanov S., Kilchenmann V., Wille H. (1985b) - Zementhonig im Honig und Brutraum was dann? II. Teil: Wirkt Zementhonig als Winterfutter toxische? Schweiz. Binenztg., 108(11): 581-590.

Krauze A., Zalewski R. I. (1991) Classification of honeys by principal component analysis on the basis of chemical and physical parameters. Z. Lebensm. Unters. Forsch., 192: 19-23.

Liebig G. (1979) - Gaschromatographische und enzymatische Untersuchungen des Zuckerspektrums des Honigtaus von Buchneria pectinatea. Apidologie, 10: 213.

Louveaux J., Maurizio A., Vorwohl G. (1978) - International Commission for Bee Botany of IUBS. Methods of Melissopalynology. Bee World, 59: 139-157.

Manzanares A. B., García Z. H., Galdón B. R., Rodríguez E. R., Romero C. D. (2011) - Differentiation of blossom and honeydew honeys using multivariate analysis on the physicochemical parameters and sugar composition. Food Chem., 126: 664-672.
Persano Oddo L., Piro R. (2004) - Main European unifloral honeys: descriptive sheets, Apidologie, 35: 38-81.

Piazza M. G., Persano Oddo L. (2004) Bibliographical review of the main European unifloral honeys, Apidologie, 35(Suppl.1): 94 $-111$.

PN-88/A-77626 (1998) - „Miód pszczeli”. [Polish Standard „Honey”] Dziennik Norm i Miar nr 8, Wydawnictwo Normalizacyjne Alfa.

Rozporządzenie Ministra Rolnictwa i Rozwoju Wsi z dnia 3 października 2003 w sprawie szczegółowych wymagań w zakresie jakości handlowej miodu [Regulation of the Ministry of Agriculture and Rural Development of Oct. 3, 2003 referring to the detailed requirements of commercial quality of honey] (Dz.U. $\mathrm{Nr}$ 181, poz. 1773 z późn. zm. Dz.U. Nr 40, poz. 370).

Rozporządzenie Ministra Rolnictwa i Rozwoju Wsi z dnia 14 stycznia 2009 w sprawie metod analiz związanych $\mathrm{z}$ dokonywaniem oceny miodu [Regulation of the Ministry of Agriculture and Rural Development of Jan. 14, 2009, detailing methods of honey assessment]. (Dz.U. Nr 17 poz. 94).

Rozporządzenie Komisji (UE) Nr 710/2010 $\mathrm{z}$ dnia 6 sierpnia 2010 r. rejestrujące $\mathrm{w}$ rejestrze chronionych nazw pochodzenia i chronionych oznaczeń geograficznych nazwę („Podkarpacki Miód Spadziowy” (ChNP)). [Commission Regulation (EU) No 710/2010 of 6 August 2010 on entering a name in the register of protected designations of origin and protected geographical indications („Podkarpacki Miód Spadziowy” (PDO))]. Dz.U. L 208/1 z 6.08.2010.

Rybak H. (1986) - Charakterystyka chemiczna krajowych miodów odmianowych. [Composition and properties of Polish unifloral honeys] Pszczeln. Zesz. Nauk., 30: 3-17.

Rybak-Chmielewska H. (2007) - High Performance Liquid Chromatography (HPLC) study of sugar composition in some kinds of natural honey and winter stores processed by bees from starch syrup. J. Apic. Sci., 51(1): 23-38. 
Szczęsna T., Rybak-Chmielewska H., Skubida P. (2003) - Contribution to the understanding of the phenomenon of "cement" honey. J. Apic. Sci., 47(2):103-108.

Szczęsna T., Rybak-Chmielewska H., Waś E., Kachaniuk K., Teper D. (2011) - Characteristics of Polish unifloral honeys. I Rape honey (Brassica napus L. var. oleifera Metzger). J. Apic. Sci., 55(1): 111-121.

Tworek K. (1998) - Spadź i jej wytwórcy. [Honeydew and its producers], in $\mathrm{J}$. Prabucki (Ed.) Pszczelnictwo [Beekeeping], Wydawnictwo Promocyjne "Albatros", Szczecin, pp. 863-879.

von der Ohe W., von der Ohe K. (1996) Characterisation of honeydew honey with specific saccharides. Apidologie, 27: 270-272.
Waś E., Rybak-Chmielewska H., Szczęsna T., Kachaniuk K., Teper D. (2011a) - Characteristics of Polish unifloral honeys II. Lime Honey (Tilia spp.). J. Apic. Sci., 55(1): 121-128.

Waś E., Rybak-Chmielewska H., Szczęsna T., Kachaniuk K., Teper D. (2011b) - Characteristics of Polish unifloral honeys III. Heather honey (Calluna vulgaris L.). J. Apic. Sci., 55(1): 129-136.

Witkowska-Żuk L (2008) - Leśne zbiorowiska roślin [Forest plant collection], in: Flora Polski, Atlas Roślinności Polski [Flora in Poland, Atlas of Polish Flora], MULTICO Oficyna Wydawnicza, Warszawa, pp. 15-70.

\title{
CHARAKTERYSTYKA POLSKICH MIODÓW ODMIANOWYCH. IV. MIÓD ZE SPADZI DRZEW IGLASTYCH, GLÓWNIE Z JODLY POSPOLITEJ (ABIES ALBA L.)
}

\author{
Rybak-Chmielewska H., Szczęsna T., \\ Waś E., Jaśkiewicz K., Teper D.
}

S t r e s z c z e $n$ i e

Uzupełniając charakterystykę polskich miodów odmianowych opisano miód spadziowy z drzew iglastych, głównie z jodły pospolitej (Abies alba). W próbkach tego miodu oznaczono cechy organoleptyczne z pomiarem barwy miodu płynnego w milimetrowej skali Pfunda oraz parametry dotyczące składu i właściwości fizykochemicznych. Klasyfikację próbek miodu przeprowadzono na podstawie zgodności cech organoleptycznych z wartościami (powyżej $0,95 \mathrm{mS} / \mathrm{cm}$ ) dla przewodności elektrycznej właściwej i obecnością charakterystycznych wskaźników spadzi (glony, zarodniki grzybów) w preparatach osadu miodowego. Z cech fizykochemicznych oznaczono: zawartość wody (od 15,3 do 18,1; średnio 16,8\%); łączną zawartość cukrów (od 71,6 do 77,9; średnio 75,3 g/100 g). Średnie zawartości $(\mathrm{g} / 100 \mathrm{~g})$ poszczególnych cukrów przedstawiały się następująco: fruktoza - 34,2; glukoza -27,8; maltoza - 3,2; turanoza - 1,8; trehaloza - 2,7 i melecytoza - 3,2 g/100 g. Oznaczono także zawartość HMF-u, wolne kwasy i pH oraz zawartość aminokwasu proliny. Potwierdzone zostały charakterystyczne dla tej odmiany cechy takie jak: wysoka przewodność właściwa (od 0,96 do $1,32 \mathrm{mS} / \mathrm{cm}$; średnio $1,14 \mathrm{mS} / \mathrm{cm}$ ) oraz bogatszy skład cukrów w stosunku do miodów nektarowych - więcej dwucukrów, niższa zawartość cukrów prostych oraz obecność melecytozy. Obecność tego trójcukru w miodach wskazuje, że powstał on w dużej części ze spadzi. W próbkach oznaczono też nieco wyższe pH (w zakresie od 4,23 do 4,99; średnio 4,63) w stosunku do miodów nektarowych. Cechy organoleptyczne miodu spadziowego ze spadzi drzew iglastych, to przede wszystkim charakterystyczna barwa. Płynny - ma barwę brązową z zielonkawym, lekko opalizującym refleksem. Po skrystalizowaniu przybiera on barwę jaśniejszą, najczęściej z wyraźnym szarawo-zielonkawym odcieniem. Zielonkawy odcień brązowej lub szaro-brązowej barwy jest cechą typową tej odmiany miodu spadziowego. Barwa próbek miodu określona w mm Pfunda 
mieściła się w zakresie od 74 - 105 (średnio 93). Świeżo odwirowany miód spadziowy posiada przyjemny zapach, przypominający nieco zapach igliwia i żywicy. Łagodny smak tego miodu ma też lekko żywiczny posmak.

Słowa kluczowe: Abies alba, miód spadziowy, charakterystyka, cechy organoleptyczne, parametry fizykochemiczne, melecytoza, Polska. 